Nippon Suisan Gakkaishi $\quad$ 74(5), 841-848 (2008)

\title{
矢作川河口周辺海域（三河湾西部）に抢ける アユ仔稚魚の分布と底質との関係
}

山本敏哉, ${ }^{*}$ 三戸勇吾, ${ }^{2 \mathrm{a}}$ 山田佳 裕, ${ }^{3}$ 野崎健太郎, 4

吉鶴靖則, 5 中田良政, 5 新見克也 5

(2006 年 6 月 22 日受付, 2008 年 4 月 17 日受理)

1豊田市矢作川研究所, 2愛媛大学大学院連合農学研究科, 3香川大学農学部,

4 椙山女学園大学人間関係学部, 5 矢作川天然アユ調査会

Relationship between distribution of larvae and juveniles of ayu Plecoglossus altivelis altivelis in the sea around Yahagi Estuary (western part of Mikawa Bay), and sediment quality

\section{ToshiYa YAMAMOTO, ${ }^{1 *}$ YUgo MITO, ${ }^{2 a}$ Yoshiniro YAMADA, ${ }^{3}$ Kentaro NOZAKI, ${ }^{4}$ YASUNORI YOSHITSURU, ${ }^{5}$ YOSHIMASA NAKATA ${ }^{5}$ AND KATSUYA NIMI ${ }^{5}$}

\begin{abstract}
${ }^{1}$ Toyota Yahagi River Institute, Toyota, Aichi 471-0025, ${ }^{2}$ The United Graduate School of Agricultural Science, Ehime University, Kita, Kagawa 761-0795, ${ }^{3}$ Department of Life Science, Kagawa University, Kita, Kagawa 761-0795, ${ }^{4}$ School of Human Sciences, Sugiyama Jogakuen University, Nisshin, Aichi 470-0131, ${ }^{5}$ Yahagi River Natural Ayu Research Association, Toyota, Aichi 471-0025, Japan
\end{abstract}

The horizontal distribution of larval and juvenile ayu Plecoglossus altivelis altivelis, and its relation to the amounts of organic matter in sediments, were investigated in the sea around the Yahagi Estuary within $4 \mathrm{~km}$ from the rivermouth in their two reproductive seasons (1st: November 2002-February 2003, 2nd: November 2003March 2004). Ayu were collected with aqua lamps within $1 \mathrm{~km}$ area from the coast, and also east of the rivermouth in both years except late February to early March when ayu annually start to ascend the river. Significant negative correlations were found between the distribution of ayu and the amounts of organic matter in the sediments; the larvae and juveniles being collected above the bottoms with less than 1\% ignition losses and less than 6 $\mathrm{mg} \mathrm{g}^{-1}$ total organic carbon content.

キーワード：アユ，底質，三河湾，矢作川河口

両側回遊性のアユPlecoglossus altivelis altivelis は，秋 に孵化した後すぐに川を流下し，春に稚魚となって河川 を遡上するまでの期間を河口域や河口周辺の海域で過ご すことが, 1980 年代の半ば以降, 土佐湾, 熊野灘, 富 山湾, 和歌山県沖で調査が進められ明らかになりつつあ る。1-9) 魚類の仔魚から稚魚までの期間は死亡率が高 く, 個体群変動の決定要因に深く関わる発育段階であ る。10)したがって，アユにとって海域での初期生活は, 遡上するアユの量を大きく左右する生活史段階と考えら れる。しかし，三河湾に拈けるアユの生態については， 1950 年代に出現状況が報告されて以降わずかな研究例
があるのみで, 仔稚魚の分布については不明のままであ る。11,12)

三河湾は水深が浅く干潟が発達するために生物の生産 性が高く，ノリ養殖などの漁業が活発におこなわれてき た。13) また, 矢作川では古くよりアユ漁が活発におこな われ，14）矢作川産のアユを育む成育場として三河湾西部 海域は主要な役割を果たしていると考えられる。しかし ながら, 三河湾は 2 つ半島によって湾口部が狭まっ ているために水の交換が悪く, 流域からの污濁水の増加 に伴って, 1970 年代以降富栄養化が進行した。例え ば, 三河湾西部 (知多湾) おける透明度は, 1950 年代

* Tel : 81-565-34-6860. Fax : 81-565-34-6028. Email : toyama@hm.aitai.ne.jp

a 現所属 : 復建調査設計株式会社 (Fukken Co., Ltd, Hiroshima 732-0052, Japan) 
の平均が $5 \mathrm{~m}$ であったのに対し，1980 年代には $3 \mathrm{~m}$ ま で減少した。13)

沿岸域に抢ける富栄養化がもたらす影響のひとつに底 質への有機物の堆積がある。15) 三河湾東部では底層への 有機物の堆積量の増大によって, 夏季の海底近くでの溶 存酸素濃度が表層の半分以下の $2 \sim 4 \mathrm{ppm}$ まで低下し， その富栄養化の程度は東京湾に匹敵するという。13)この 溶存酸素濃度の低下に伴い発生する貧酸素水塊により, 底生動物等への漁業被害が度々生じている。16) 魚類では 底生魚を中心に棲息域が消減する等の影響が各地で懸念 されているが, 16-18) 本海域に打いて底質の有機污濁が魚 類へもたらす影響の評価をおこなった研究は乏しい。特 に，海域に抢けるアユの初期生態と底質との関係につい てはこれまで報告がなされていない。一方，矢作川河口 周辺の底質には水平分布に河口より $5 \mathrm{~km}$ 以内の範囲で 大きな違いがみられ，有機物の含有量で 10 倍以上の差 がある。 $\mathrm{km}$ の範囲において 2 年間にわたるアユ仔稚魚の採集結 果に基づいて分布の特徵を記載するとともに，底質の有 機物量との関係を中心にアユの初期生態におよぼす影響 を明らかにしようと試みた。

\section{材料および方法}

矢作川は, 長野県の大川入山を源流に愛知県の中央部 を流れ，三河湾西部（知多湾）に流入する。その幹線流 路延長は $117 \mathrm{~km}$, 流域面積は $1830 \mathrm{~km}^{2}$ におよぶ。20) 矢 作川が流入する知多湾は, 表面積が $149 \mathrm{~km}^{2}$, 平均水深 $7.1 \mathrm{~m}$ を有し，その集水面積の 9 割以上を矢作川が占め ている。 ${ }^{15)}$

海域でのアユ仔稚魚の調査は一般的に稚魚ネットが使 用されるが，矢作川河口周辺の海域では秋から冬にかけ てノリ養殖の粗氺が海岸近く立てられるため, ネットの 曳網可能な範囲が限られる。このため今回の調查には, 集魚灯 $(200 \mathrm{~W})$ による採集方法を採用した。

アユ仔稚魚の採集は, 矢作川の河口沖合の海域に打い て 2002 年の 11 月から 2003 年の 3 月, 2003 年の 11 月 から 2004 年の 3 月上旬まで, 月に 1 回の頻度で行なっ た。河口より沖合方向への調査範囲は, 他海域ではアユ 仔稚魚の主要な分布域が河口より $3 \mathrm{~km}$ 沖までの範囲に あるとの報告 $5,6,9)$ に基づき, 河口より $4 \mathrm{~km}$ の範囲まで とした。採集地点は, 2002 年度は Fig. 1 に示した地点 1 から 8 までの 8 地点とした。2002 年度には沖合側の 地点でアユがほとんど採集されなかったため, 2003 年 度には地点 3 4 と 7 8 を除外し, 岸から沖合 $1 \mathrm{~km}$ ま での地点 $1 \sim 2$ と $5 \sim 6 の 4$ 地点と, 新たに設定した地 点 9 から 12 までの 4 地点の合計 8 地点で行った。調查 地点の水深は, 2002 年度は $2 \sim 16 \mathrm{~m}, 2003$ 年度は 1.5 〜 9 mであった。

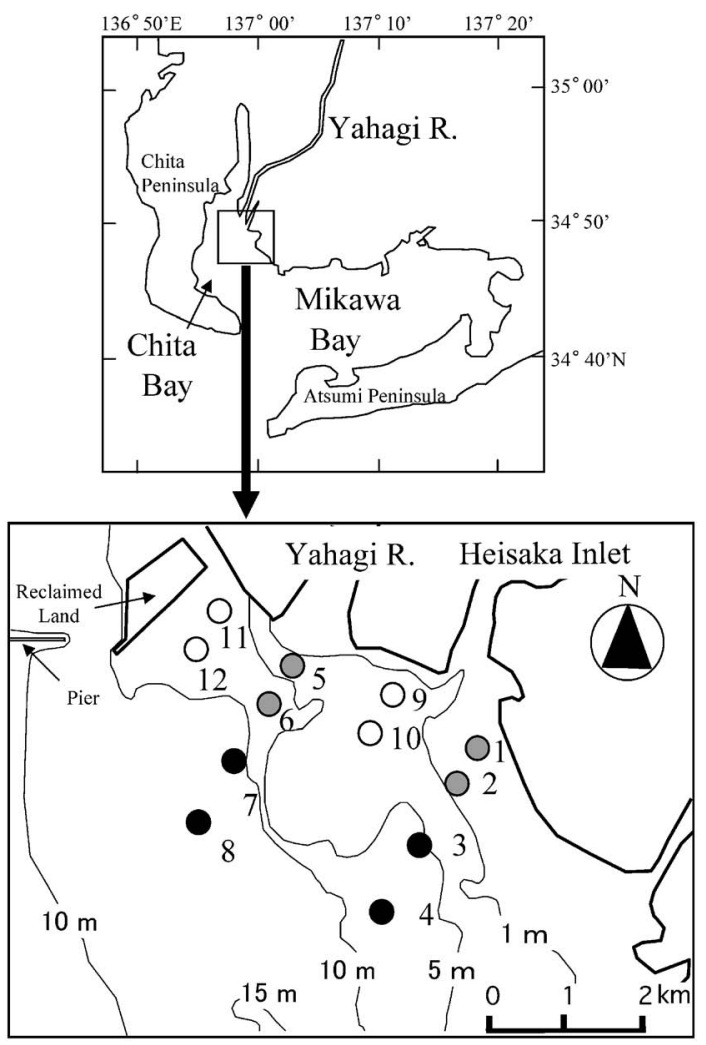

Fig. 1 Map showing sampling sites in the sea around Yahagi Estuary. Black circles are sites collected only in November 2002 February 2003; white ones only in November 2003 March 2004; grey ones in both seasons.

各地点では日没直後に船から集魚灯を水面直下へと垂 らし，30 分間点灯してその間に集まる仔稚魚を 2 人が 同時にタモ網で採集した。タモ網は 2 種類を用意し (口径 $20 \mathrm{~cm}$, 網目 $1 \mathrm{~mm}$; 口径 $30 \mathrm{~cm}$, 網目 $3 \mathrm{~mm}$, 採 集されるアユのサイズにより使い分けた。採集日は大潮 から中潮の日没直後から没後 3 時間以内に満潮になる 日を選んだ。得られた試料は，5％ホルマリン溶液で 2 ～6 時間固定後， $70 \%$ エタノールで保存した。採集の 際には表層抢よび底層の水温と塩分を多項目水質計（堀 場製作所，水質チェッカーU-21）により測定した。各 サンプルのアユ仔稚魚の個体数を計数後, 全個体の体長 を測定した。得られたデータより, 分布の特徵, 体長組 成の地点間での差などについて考察を加えた。

地点ごとのアユ仔稚魚採集数と底質との関係を検討す るために， 2002 年 12 月 22 日と 2003 年 12 月 29 日 に, 全ての調査地点で底質の採集を抢こなった。調査期 間中は温度が低く，また大きな出水も少ない時期であり 底質は比較的安定していると考えられたため, 各年 12 月に 1 回の調查とした。底質はエクマンバージ型採泥 器 (5141A, 離合社, 採泥面積 $0.02 \mathrm{~m}^{2}$ ) により採取し, スプーンで表層の $5 \mathrm{~mm}$ 程度を分析用サンプルとした。 
底質がアユ仔稚魚の生息に対して影響をおよぼすプロセ スの一つに，底質中に含まれる有機物の分解に伴って酸 素の消費が進むとともに，底質の間隙水が還元され，生 物に有害な無機イオンが溶出してアユへ作用する可能性 がある。そこで有機物量の含有量の目安として，2002 年度のサンプルは強熱減量を測定し， 2003 年度はより 厳密に把握するために三戸らが報告した全有機炭素量の データ19)を用いた。強熱減量の測定は, 西条, 三田 村 ${ }^{21)}$ に記載された方法に基づいて採集した底質の $110^{\circ} \mathrm{C}$ での乾燥重量を計測した後, $600^{\circ} \mathrm{C}$ の電気炉で 2 時間燃 焼させその減少量を測定した。全有機炭素量の測定で は, 試料に酸処理を施し無機炭酸を除去した上で，元素 分析計（MT-5，ヤナコ分析工業）を用いた。 ${ }^{19)}$

\section{結果}

集魚灯による仔稚魚の採集 Table 1 に調査日ごとの アユ仔稚魚の採集結果を示した。全ての調査日にアユ仔 稚魚は出現し, 2002 年度には 427 尾（9.2 58.8 mm $\mathrm{BL}), 2003$ 年度には 36 尾 $(20.0 \sim 60.1 \mathrm{~mm} \mathrm{BL})$, 合計 463 尾が採集された。Fig. 2 に 2002 年度の地点ごとの 採集数を月別に示した。地点ごとの採れ方の大きな特徵 に, 矢作川の流路と平行に調査地点同士を結んだ 2 本 のラインのうち, 東側のライン（地点 $1 \sim 4 ）$ で毎月顕 著に多く採集され (407 尾), 西側のライン (地点 $5 \sim 8$, ) の採集尾数を合計した数 (20 尾)の 20.4 倍に抢よんだ。 また，このライン上では各月とも岸に近い地点ほど多く 採集された。Fig. 3 に 2003 年度の地点ごとの採集数を 月別に示した。合計の採集数は 36 尾と 2002 年度の 10 分の 1 に満たなかったものの，2002 年度と同じく東端 の 2 地点（1 2）でアユ仔稚魚が多く採集され（4回通 算して 23 尾)，全体の $64 \%$ を占めていた。対照的に, 西端の 2 地点（11～12）からはアユ仔稚魚は全く採集 されなかった。矢作川に最も近い地点 5 では, 両年々 も最終回の 2 月下旬以降の調查日に比較的まとまった
数のアユが採集された（2002 年度 ; 9 尾， 2003 年度 ; 10 尾)。

仔稚魚の体長の比較 離岸距離に伴って体長が変化す るかどうかを検討するために，2002 年度に採集された アユ仔稚魚の地点別の体長組成を Fig. 4 に示した。地 点 3 で 25〜 40 $\mathrm{mm}$ の, 地点 5 で 40 55 $\mathrm{mm}$ の比較的 大きい個体が採集された他は, 全体として体長 $20 \sim 30$ $\mathrm{mm}$ にモードが存在した。Fig. 5 に 2002 年度に設定し た東側のライン $(1 \sim 4)$ と西側のライン $(5 \sim 8)$ ごと に集計した体長組成を示した。両ラインとも体長 20 〜 $30 \mathrm{~mm}$ の間に頻度のピークがあり, 西側のラインでは $45 \mathrm{~mm}$ 以上のサイズにも一つのピークが認められた。 これは 2003 年 2 月 21 日に地点 5 で採集された個体か ら構成され (Fig. 4), それらの平均体長 $(54.1 \mathrm{~mm}, n$
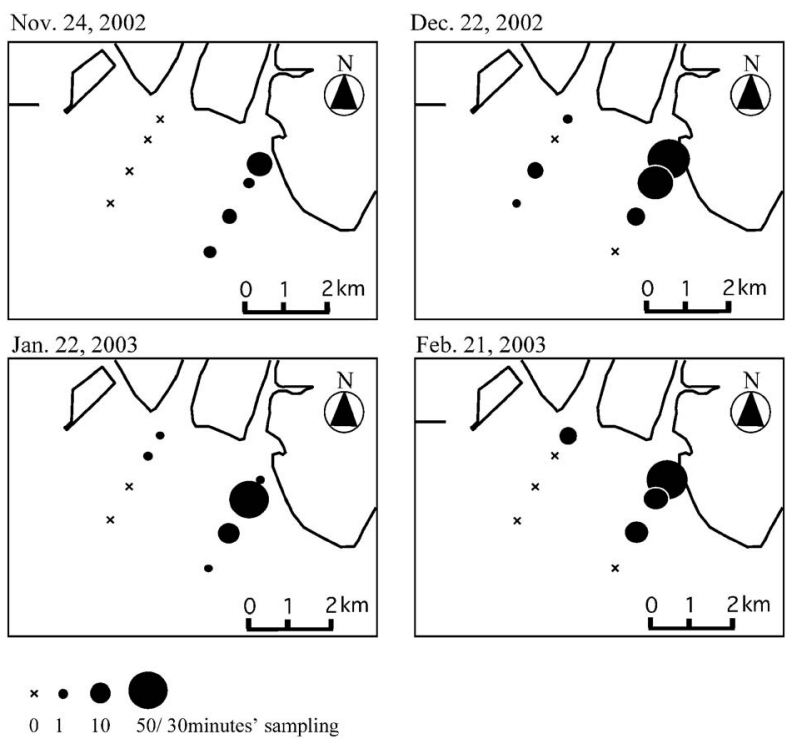

Fig. 2 Catch abundance of ayu by aqua lamps in November $2002 \sim$ February 2003 . The diameter of each circle is drawn in proportion to the cube root of the catch number per 30 minutes.

Table 1 Collection records of ayu larvae with aqua lamps (200 W) in the sea around Yahagi Estuary from November 2002 to February 2003 and from November 2003 to March 2004

\begin{tabular}{|c|c|c|c|c|c|c|c|c|}
\hline \multirow{2}{*}{$\begin{array}{l}\text { Fiscal } \\
\text { Year }\end{array}$} & \multirow{2}{*}{ Date } & \multirow{2}{*}{$\underset{\text { time }}{\text { Sampling }}$} & \multirow{2}{*}{$\begin{array}{l}\text { Total no. } \\
\text { of ayu }\end{array}$} & \multirow{2}{*}{$\underset{(\mathrm{mm})}{\text { Range of BL }}$} & \multicolumn{2}{|c|}{ Range of W.T. $\left({ }^{\circ} \mathrm{C}\right)$} & \multicolumn{2}{|c|}{ Range of salinity $(\%)$} \\
\hline & & & & & Surface & Bottom & Surface & Bottom \\
\hline \multirow[t]{4}{*}{2002} & Nov. 24, 2002 & $17: 20-19: 40$ & 33 & $9.2-23.4$ & $14.8-16.1$ & $14.8-15.2$ & $30.0-32.8$ & $31.5-33.1$ \\
\hline & Dec. 22,2002 & $17: 20-20: 00$ & 156 & $17.3-34.8$ & $11.5-11.9$ & $10.7-11.9$ & $30.1-32.2$ & $31.6-32.8$ \\
\hline & Jan. 22,2003 & $17: 30-19: 50$ & 99 & $20.6-32.0$ & $8.8-9.6$ & $8.6-9.5$ & $30.5-32.1$ & $31.9-32.6$ \\
\hline & Feb. 21, 2003 & $18: 10-20: 30$ & 139 & $23.8-58.8$ & $9.3-9.9$ & $9.4-9.7$ & $29.9-32.3$ & $31.8-32.5$ \\
\hline \multirow[t]{4}{*}{2003} & Nov. 30,2003 & $17: 30-19: 40$ & 2 & $20.0-29.5$ & $13.3-17.7$ & $16.8-17.4$ & $23.7-31.7$ & $27.6-32.0$ \\
\hline & Dec. 29, 2003 & $17: 10-19: 30$ & 4 & $23.7-27.1$ & $12.1-12.8$ & $12.4-12.7$ & $29.3-32.0$ & $29.5-32.0$ \\
\hline & Jan. 31,2004 & $18: 30-20: 40$ & 16 & $23.5-48.5$ & $9.5-10.6$ & $9.6-10.7$ & $28.7-31.0$ & $29.0-31.0$ \\
\hline & Mar. 1, 2004 & $18: 10-21: 00$ & 14 & $31.9-60.1$ & $9.9-12.0$ & $10.0-12.0$ & $27.5-32.0$ & $30.6-32.0$ \\
\hline
\end{tabular}



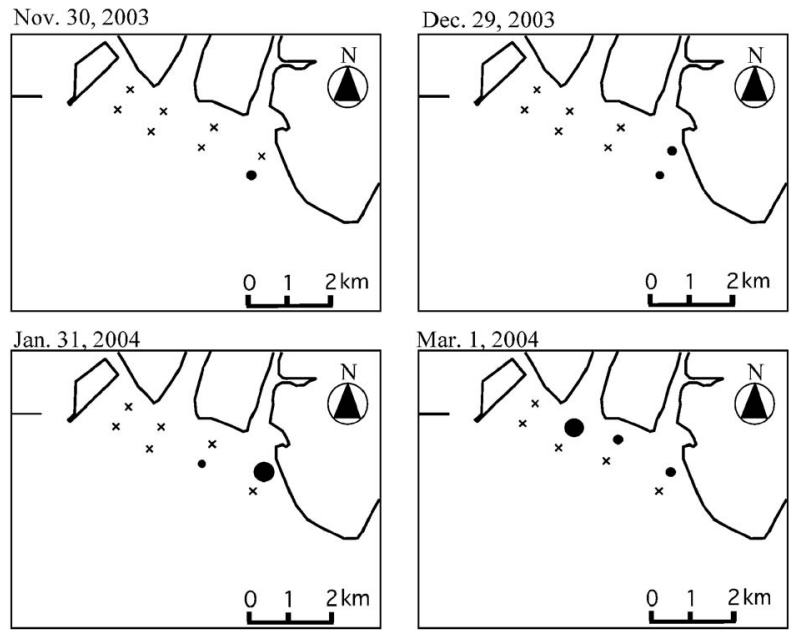

$\times$

$\begin{array}{llll}0 & 1 & 10 & 50 / 30 \text { minutes' sampling }\end{array}$

Fig. 3 Catch abundance of ayu larvae by aqua lamps in November 2003 March 2004. The diameter of each circle is defined as in Fig. 2.

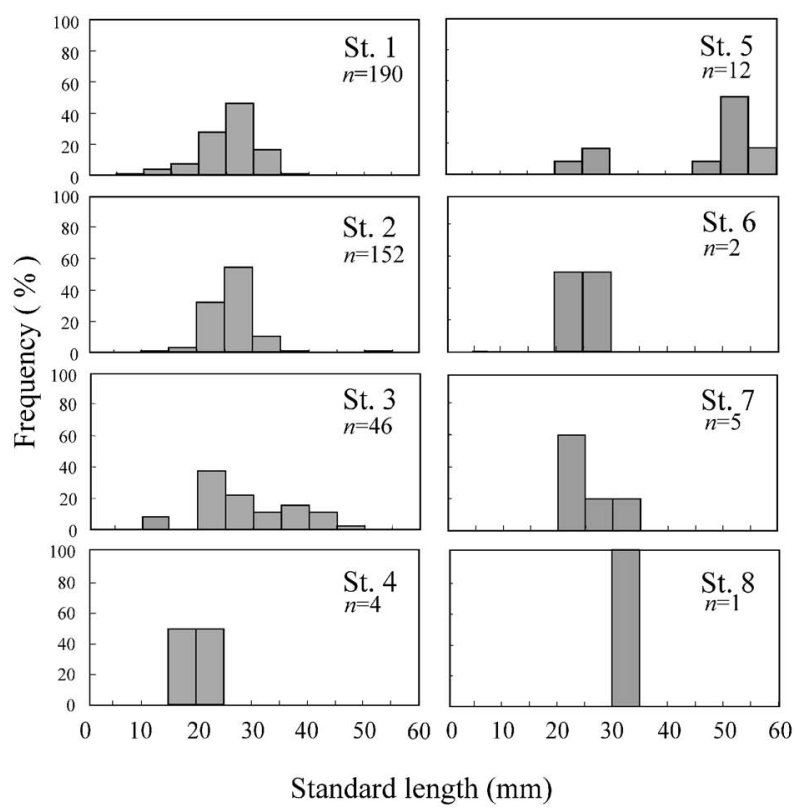

Fig. 4 Comparison of length distributions of ayu collected in November 2002 February 2003 at each station.

=9）は他の地点のアユ（31.6 mm, $n=34 ）$ よりも大き $<(t$ 検定, $p<0.001)$, シラス型から成魚の形態への 変態を完了した個体であった。同様の傾向は 2004 年 3 月 1 日の調査でもみられた（地点 5 , 平均体長 55.8 $\mathrm{mm}, n=10$; 地点 5 以外, $42.0 \mathrm{~mm}, n=4, t$ 検定 $p<$ 0.001)。Fig. 6 に 2002 年度と 2003 年度の標本をそれ ぞれ集計した体長組成を示した。両年度とも $25 \sim 30$ $\mathrm{mm}$ にモードがみられるが，2002 年度は 2003 年度より

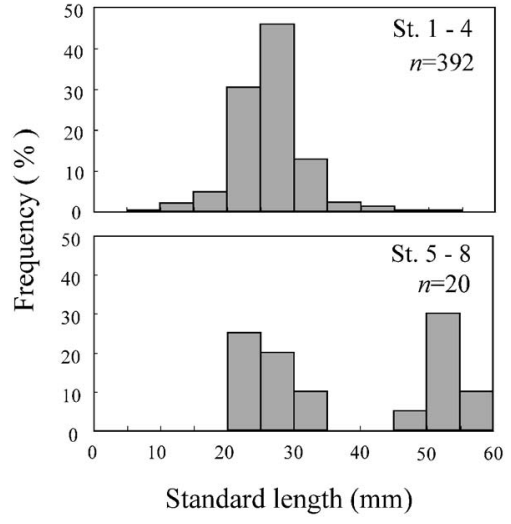

Fig. 5 Comparison of length distributions of ayu collected along two lines parallel to the Yahagi River from November 2002 to February 2003: A, eastern line (1 $4)$; B, western line $(5 \sim 8)$.

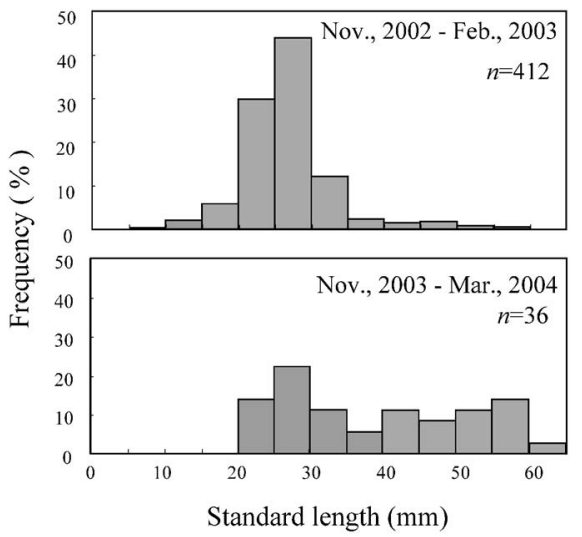

Fig. 6 Comparison of length distributions of ayu between samples collected in November 2002 February 2003 and in November 2003 March 2004.

$20 \mathrm{~mm}$ 前後の個体の割合が高かった。

底質の有機物量 エクマンバージ採泥器で採取した地 点ごとの底質は，泥質か貝殸の多く混じった砂質であっ た。Fig. 7 に地点ごとの底質の強熱減量（2002 年度） と全有機炭素量（2003 年度）を示した。2002 年度に採 取した底質の強熱減量は， $0.4 〜 11.7 \%$ の範囲にあっ た。このうち矢作川の流路を延長したライン上 $(5 \sim 8)$ の強熱減量（3.7～11.7\%）は，東側のライン（1～4) のそれ $(0.4 \sim 1.2 \%)$ と比較して，平均で 12.1 倍の差 があり有意に高かった（Mann-Whitney $U$ 検定， $p<$ $0.01) 。 2003$ 年度に採取した底質の全有機炭素量は, 1.9 27 $\mathrm{mg} \mathrm{g}^{-1}$ の範囲にあり, 8 地点のうち矢作川河口 に近い 6 地点 $(5,6,9,10,11,12)$ の平均值が $15.3 \mathrm{mg}$ $\mathrm{g}^{-1}$ であったのに対し, 最も東側の 2 地点 $(1,2)$ の平 均值は $3.6 \mathrm{mg} \mathrm{g}^{-1}$ と低く, 4.3 倍の差があった。このよ うに，調査を行った範囲では，矢作川の河口に近い地点 で有機物量の含有量が多く, 河口から離れた東側の地点 

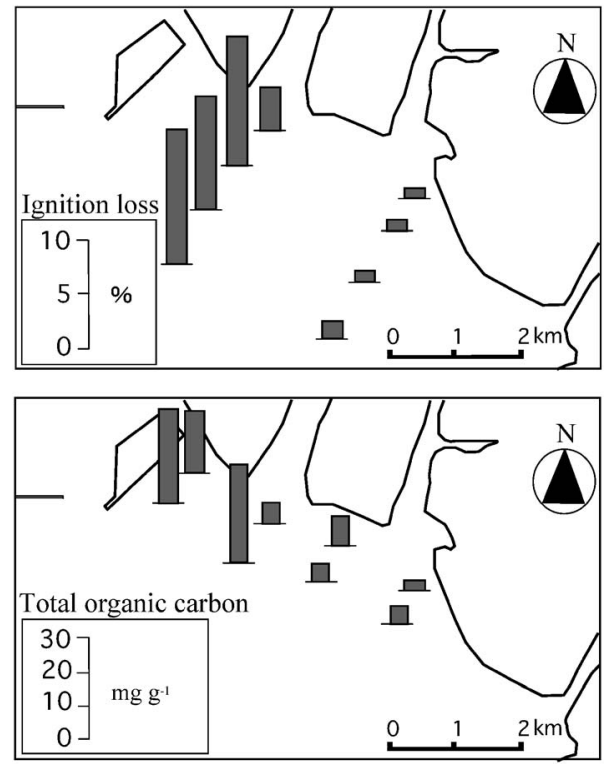

Fig. 7 Ignition losses (upper) and total organic carbon content (lower) in sediment smaller than $250 \mu \mathrm{m}$ in the Yahagi Estuary.

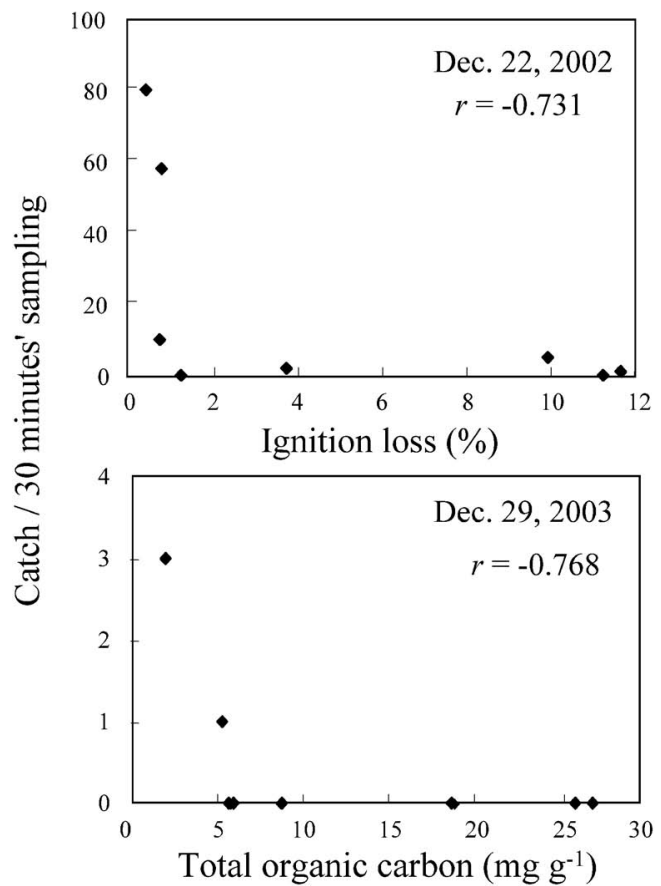

Fig. 8 Relationship between catch number of ayu and total organic content in the sediment.

でその含有量が少ない傾向がみられた。

Fig. 8 に 12 月の調查時のアユ仔稚魚の採集数と底質 の強熱減量 (2002 年度) および有機炭素量 (2003 年度) との関係を示した。両年とも有意な負の相関がみられ （スピアマン順位相関係数 ; 2002 年度, $r=-0.731, p<$ $0.01 ; 2003$ 年度, $r=-0.768, p<0.01), 2002$ 年度には
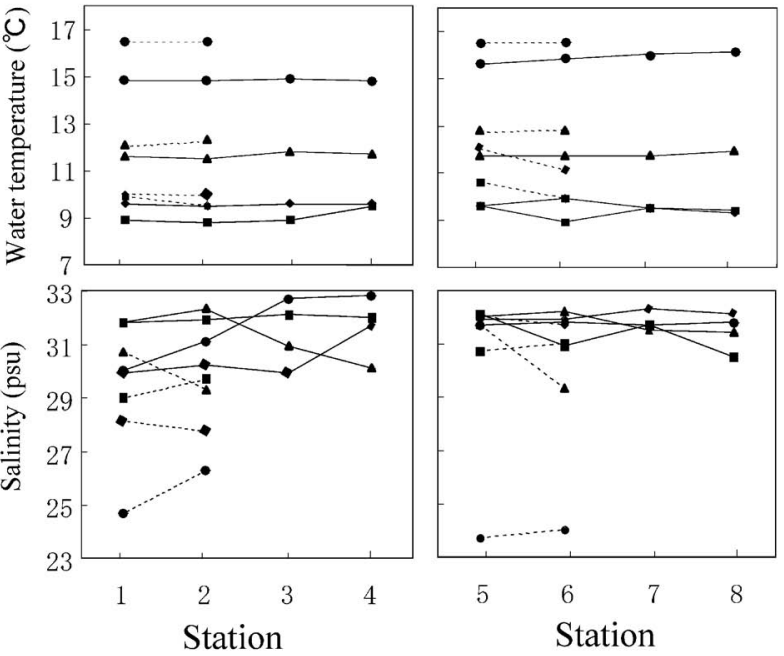

\begin{tabular}{|c|c|}
\hline$\longrightarrow$ Nov. 24, 2002 & $\cdots$ Nov. 30, 2003 \\
\hline$\rightarrow$ Dec. 22, 2002 & $\cdots \star$ Dec. 29,2003 \\
\hline$\rightarrow-$ Jan. 22, 2003 & $\cdots$ Jan. 31,2004 \\
\hline$\bullet \quad$ Feb. 21, 2003 & $\cdots$ Mar. 1, 2004 \\
\hline
\end{tabular}

Fig. 9 Water temperature and salinity along two inshore -offshore lines $(1-4,5-8)$ in November $2002 \sim$ February 2003 and in November 2003 March 2004.

底質の強熱減量が $1 \%$ 未満の底質からは, 30 分間の調 査でアユ仔稚魚が 10〜80 尾採集されたのに対し，1\% 以上の地点からは 5 尾以下にとどまった。一方の 2003 年度には，アユ仔稚魚が採集されたのは底質の全有機炭 素量が $5.2 \mathrm{mg} \mathrm{g}^{-1}$ 以下の地点に限られていた。

調査時の水温と塩分 調査時の水温は $8 \sim 18^{\circ} \mathrm{C}$ の範 囲にあり，11月下旬が最も高く 1 月下旬が最も低かっ た（Table 1)。塩分は 2002 年度には $30 \sim 33 \mathrm{psu}$ の範 囲にあったのに対し，2003 年度には 11 月下旬に最も低 い地点では $23.7 \mathrm{psu}$ となった (Table 1)。次に河川水 の影響を検討するために， 2 本の調査ライン（1４ ～お よび 5８）上の岸から沖方向への表層の水温と塩分の 観測值をFig. 9 に示した。水温はこの方向でほぼ同じ 值で推移した。塩分は同じ值で推移した場合に加え, 調 査日によって最大で $3 \mathrm{psu}$ 程度増減したが，岸から沖方 向で塩分が高くなる明瞭な傾向は認められなかった。 2003 年度は, 11 月 30 日のみ 4 地点とも大きく塩分が 低下していた。また, 地点間でばらつきのみられた塩分 についてアユ仔稚魚との相関を調べたものの, 有意な差 はみられなかった（スピアマン順位相関係数；2002 年 度, $r=-0.148, n s ; 2003$ 年度, $r=-0.128, n s)$ 。

\section{考察}

集魚灯による採集の結果，アユ仔稚魚は矢作川河口の 東側海域（1４）で主に採集され，矢作川の流路の延 長上にある地点（5～8） からはその 20 分の 1 以下しか 
採集されなかった。熊野川河口の沖合での調査報告によ ると, アユ仔稚魚が採集されたのは岸から $2 \mathrm{~km}$ 以内に 限られ，2〜 $40 \mathrm{~km}$ の沖合側では 1 尾も得られていな い。5）また，富山湾に流入する神通川および庄川，土佐 湾中央部に流入する仁淀川河口沖合の調査によれば, ア 工仔稚魚は主に海岸から沖合 $3 \mathrm{~km}$ までの範囲で分布し たと報告されている。6,9) したがって矢作川河口から4 $\mathrm{km}$ までの範囲に設定した今回の調査地点は, 矢作川を 流下したアユ仔稚魚の主要な生息場所と推察されるが, アユ仔稚魚の出現が調査範囲の一部に限られ, しかも河 口に最も近い地点で少数しか採集されなかったことは, 本海域では沖合 $3 \mathrm{~km}$ までの範囲でもアユ仔稚魚の分布 に水平的な偏りが存在する可能性を示唆する。

次に, アユ仔稚魚の分布に偏りがみられた原因とし て, 水深, 河川流量, そして底質の有機物量に関し順に 検討する。今回の 12 ヶ所にわたる調査地点の水深は 1.5 16 m と大きな差があった。これを他の水域でアユ 仔稚魚が出現した場所の水深と比較すると, 四万十川の 河口域では, 水深 $3 \sim 15 \mathrm{~m}$ までの流心部で体長 $20 \sim 25$ $\mathrm{mm}$ をモードとしたアユ仔稚魚が集魚灯によって表層で 採集されている。22) 水深が深く塩分躍層が発達する富山 湾では, 塩分躍層より上層の水深 $1 \mathrm{~m}$ 以浅の表層に多 くのアユ仔魚が分布することが知られている。6 これら のことから, 今回調査した水深 $16 \mathrm{~m}$ までの地点の間で は, 深さに関係なくどの地点でもアユ仔稚魚が出現して 不思議ではない。

河川水に由来する流れによってアユが定着できない可 能性に関し，河口域でのアユ仔稚魚の分布に関する他の 河川の報告を検討した。四万十川や熊野川では一部のア 工仔稚魚が海域へ降河せず, 砂嘴で狭まった河口部より 上流の塩分濃度の低い水域で滞留することが報告されて いる。2,5) 熊野川ではさらに, 河口部の沖合 $40 \mathrm{~km}$ に及 ぶ範囲の海域を複数のネットを用い調べたが，アユ仔稚 魚が出現したのは沖合 $2 \mathrm{~km}$ までの塩分の低い水域に限 られていた。また, 高知県内の流程 $30 \mathrm{~km}$ 程度の比較 的小規模な河川に抢いて 3 年間にわたって集魚灯を用 いて調査した報告でも，年によって降水量に 5 倍程度 の差あり河川流量に相当な年較差があったと想定される にも関わらず，河口付近（河口より約 $400 \mathrm{~m}$ 上流の調 查地点）で毎年アユ仔魚が 11 月 1 月の間に継続的に 採集されている。23)このように他河川の事例と比較する と, 今回の矢作川での調查地点よりも河川水の影響をよ り強く受ける可能性の高い河口近くの水域で, アユ仔魚 が分布する事例が複数ある。したがって，今回の調査範 囲とした矢作川の河口より $4 \mathrm{~km}$ までの範囲の海域にお いて, アユ仔稚魚が採集されなかった原因に, 河川水の 流れの影響が強く働くとは考えにくい。

アユ仔稚魚の分布は, 2 年とも底質の有機物量の間に
有意な相関がみられた。このような底質の有機物量と生 物, 特に魚類の分布との関係に言及した研究事例は乏し く, 特にアユ仔稚魚に関しては初めてである。

三戸ら ${ }^{19)} の$ 底質分析の結果によれば, 2003 年の調査 地点とした 8 地点中, 東側の 4 地点（地点 $1 \sim 2,9 \sim 10$ ) では粒度の中央值が 250 500 $\mu \mathrm{m}$ の範囲にあったのに 対し, 河口に一番近い地点を除いた残りの 3 地点（地 点 $6,11 \sim 12)$ では $125 \mu \mathrm{m}$ 以下, 河口に最も近い地点 5 が 125 250 $\mu \mathrm{m}$ と, 有機物量に比例して粒度が小さ くなる傾向にある。つまり, 有機物を比較的多く含んだ いわゆるへドロ状の底質の場所において, アユ仔稚魚が 出現しなかったといえる。

また三戸ら ${ }^{19)}$ は, 炭素の安定同位体比成分の分析結 果から, 矢作川河口周辺の海域に堆積した微細な有機物 は矢作川由来であり，底質環境に大きな変化を与えてい ると述べている。東京湾でも, 河口沖に堆積した底質が 河川由来であるとの報告がなされている。矢作川の河 口周辺の海域で長年にわたり漁業を営んできた漁業者に よれば，このような泥状の有機物は $30 \sim 40$ 年以前には 存在しなかった（斉藤弘太郎氏私信）とのことからこ の間の矢作川に生じた環境変化の結果かもしれない。

今回の底質の調査結果を他の海域で報告されている結 果と比較すると, 国内で最も富栄養化の進行した海域で ある東京湾 ${ }^{24)}$ と大阪湾25) に打汀底質中の有機炭素量 の最大值は $30 \mathrm{mg} \mathrm{g}^{-1}$ 程度である。今回の 2003 年度の 調査では, 8 地点のうち矢作川河口に近い 6 地点 $(5,6$, $9,10,11,12)$ の平均值は $15.3 \mathrm{mg} \mathrm{g}^{-1}$, 最も高かった地 点では $27 \mathrm{mg} \mathrm{g}^{-1} の$ 值が観測された。また, 今回の調 查の範囲外も含めた三河湾西部（知多湾）全域において は, 東域の湾口部にかけての海域では全有機炭素量が $10 \mathrm{mg} \mathrm{g}^{-1}$ 未満であるものの, 湾の西域, 中央域の南側 そして北域に抢いて $17 \sim 31 \mathrm{mg} \mathrm{g}^{-1}$ の有機物が含まれ る底質が広がると報告されており, ${ }^{19)}$ 三河湾西部は全体 としてかなり底質の有機污濁が進行した海域といえる。

有機物を多く含んだ底質がアユ仔稚魚に扮よぼす影響 としてまず考えられるのは, 酸素が底層で消費されるた めに貧酸素な環境となり，それがア工仔稚魚の生息を制 限している可能性である。実際, 三河湾では年によって 夏に貧酸素水塊が生じ, アサリ等の漁業被害が発生して いる。16) アユが出現する 11 月から 3 月にかけての三河 湾は, 水が鉛直混合する時期にあたるため貧酸素水塊が 発生しないが，規模は小さくても有機物の堆積した海底 では海底直上の水質が還元的な状態となる可能性があ る。一般的に, 底質が還元的な環境になると, 生物に有 害な硫化水素やマンガンなどの無機イオンが溶出するこ とが知られている。 ${ }^{26)}$ 今回の調査ではアユの分布水深が 把握できていないため, 底層近くの環境を関連づけて議 論を深めることはできないが，矢作川河口周辺海域での 
アユ仔稚魚の生息環境を考える上で，底質が影響するプ ロセスに注目して今後さらに踏反込んだ調査が必要であ る。

その他, 矢作川河口周辺でのアユ仔稚魚の分布状況に 関し，矢作川の河口近くの地点で 2003 年 2 月に採集さ れた体長 45〜60 mm のアユは, 他の地点よりも有意に 体長が大きかった。同様の傾向は 2004 年 3 月の調査で もみられ，これらは河川への遡上を控え河口付近に集ま ったアユと推測できる。

2002 年と 2003 年の採集数を両年とも調査を行った 4 地点（1～2, 5 6）について比較すると, 2002 年が合 計 371 尾採集されたのに対し, 2003 年は 33 尾と 2002 年の 10 分の 1 以下にとどまった。この要因として，ま ずアユ仔魚の流下数が大幅に異なることが考えられるた め, アユ仔魚の流下量を矢作川の河口より $10.6 \mathrm{~km}$ 上 流で 10 月上旬より 12 月中旬まで行った流下仔魚の調 查の結果 ${ }^{27)}$ と同じ場所で国土交通省中部地方整備局の 豊橋河川事務所が観測した河川流量（確定値）を加味し て検討した。その結果，両年の間では 2002 年が 2003 年よりも約 5 倍多い流下数と概算された。次に 2002 年 と 2003 年の $10 \sim 12$ 月のこの河川流量を比較したとこ 万, 2003 年の 11 月と 12 月の河川流量がそれぞれ 49.8 $\mathrm{t} \mathrm{s}^{-1}$ と $46.5 \mathrm{t} \mathrm{s}^{-1}$ と, 2002 年の同じ時期 (11月， 11.9 $\mathrm{t} \mathrm{s}^{-1} ; 12$ 月, $\left.14.6 \mathrm{t} \mathrm{s}^{-1}\right)$ と比較して $3 \sim 4$ 倍の流量が あった。今回の調査で観測した塩分濃度が 2003 年の 11 月と 12 月に低かったのも, この河川流量の増大の結果 と考えられる。一方, 和歌山県中部 ${ }^{8}$ と高知県西部 23 の 砕波帯でアユ仔魚の分布を調べた研究では, 硗波帯に新 たに加入したアユ仔魚は，アユ仔魚が孵化した河川の流 域の降水量が多い時期ほどその分布範囲が広がる傾向に あると報告されている。以上の点を考慮すると, 今回の 調査で 2003 年度にアユ仔稚魚の採集数が大幅に減少し たのは, アユ仔魚の流下数が 2002 年よりも少なかった ことに加え，2003 年のアユ仔魚が流下する時期の河川 流量が多く, アユ仔魚がより広範囲に分散したことが一 因と考えられる。

本論文では, アユの分布と底質の有機物量との間に強 い負の相関関係がみられることを明らかにし，想定され る影響のメカニズムに関し考察を加えた。しかし一方 で，アユの分布を決定する要因にはエサの密度や潮流等 の水の動きも関与している可能性がある。今回はそれら に関しデータにもとづく十分な検証はできていない。ま た，矢作川に由来する有機物がどのようなメカニズムで 堆積するに至ったのか, 現時点では大型ダムの建設によ る河川生態系の变化, 工業化の進展に伴う污濁負荷量の 増大等が可能性として指摘できるが，その寄与の程度は 不明である。今後, 底質中の有機物がアユ仔稚魚へ抢よ ぼす影響のメカニズムを探るとともに，仔稚魚の鉛直分
布の調査, エサ密度と水の動きの把握, そしてこの有機 物の堆積に至った原因を視野に入れた研究も推進してい く必要がある。

\section{謝辞}

本研究を進めるにあたり, 様々な助言をいただいた高 橋勇夫博士, 大竹二雄博士, 小嶋純一博士に深謝する。 現地調査にあたり，ご協力をいただいた中部電力株式会 社エネルギー応用研究所の濱田稔氏, 一色漁業協同組合 の鈴木信治組合長, 西尾漁業協同組合の坂部義明氏, 坂 部守氏に厚く御礼申し上げる。

\section{文献}

1) Senta T, Kinoshita I. Larval and juvenile fishes occurring in surf zones of western Japan. Trans. Am. Fish. Soc. 1985; 114: 609-618.

2）高橋勇夫, 木下 泉, 東 健作, 藤田真二, 田中 克. 四万十川河口内に出現するアユ仔魚. 日水誌 1990; 56: 871-878.

3) Takahashi I, Azuma K, Fujita S, Kinoshita I. Spatial distribution of larval ayu Plecoglossus altivelis in the Shimanto Estuary, Japan. Fish. Sci. 1998; 64: 522-525.

4) Takahashi I, Azuma K, Fujita S, Kinoshita I, Hiraga H. Annual changes in the hatching period of the dominant cohort of larval and juvenile ayu Plecoglossus altivelis altivelis in the Shimanto Estuary and adjacent coastal waters during 1986-2001. Fish. Sci. 2003; 69: 438-444.

5）塚本勝巳, 望月賢二, 大竹二雄, 山崎幸夫. 川口水域に 打けるアユ仔稚魚の分布・回遊・成長. 水産土木 1989 ; 25: 47-57.

6）田子泰彦. 富山湾の河口域およびその隣接海域表層にお けるアユ仔魚の出現・分布. 日水誌 $2002 ; 68: 61-71$.

7）田子泰彦. 富山湾の砂浜域砕波帯周辺におけるアユ仔魚 の出現, 体長分布と生息場所の変化. 日水誌 $2002 ; 68$ : 144-150.

8）東 健作, 平賀洋之, 堀木信男, 谷口順彦. 和歌山県中 部の砕波帯におけるアユ仔魚の分布. 水産増殖 2002; 50: 9-15.

9）八木佑太, 美藤千穂, 舟越 徹, 木下 泉, 高橋勇夫. 土佐湾沿岸域におけるアユ仔魚の分布および食性. 日水 誌 2006; 72: 1057-1067.

10）南 卓志. 初期減耗研究の方法論 - 研究の歴史. 「魚類の 初期減耗研究」（田中 克, 渡邊良朗編）恒星社厚生閣, 東京. 1994; 9-20.

11）堀田秀之. 海産稚鮎の生態に就いて. 魚雑. 1953; 3: 1520.

12）山本敏哉. 矢作川河口周辺海域におけるアユの初期生活 - I . 矢作川研究, 豊田市矢作川研究所, 愛知. 2003; 7: 177-185.

13）佐々木克之. 失われゆく三河湾の生態系. とりもどそう 豊かな海三河湾一「環境保全型開発」批判（三河湾研究会 編）八千代出版, 東京. 1999; 37-61.

14）芝村龍太.川の権利をめぐって.「環境漁協宣言」（矢作 川漁協 100 年史編集委員会編）風媒社, 愛知. 2003; 53114.

15）佐々木克之, 鈴木輝明, 松川康夫, 佐藤善徳. 富栄養化 と物質循環. さかな $1981 ; 26: 45-70$.

16）中村元彦, 黒田伸郎. 伊勢 -三河湾に打ける漁業の推 移. 綜合郷土研究所紀要 2005; 50: 239-252. 
17）田北 徹, 山口敦子. 魚類の変化. 「有明海の生態系再生 を目指して」（日本海洋学会編）恒星社厚生閣, 東京. $2005 ; 128-132$.

18）河野 博. 東京湾とはどんなところだろう.「東京湾 魚 の自然史」(東京海洋大学魚類学研究室編)平凡社, 東京. 2006; $17-29$.

19）三戸勇吾, 山田佳裕, 山本敏哉, 中島沙知, 白金晶子, 堤 裕明, 多田邦尚. 知多湾における堆積物中の有機物 の起源. 日水誌 $2007 ; 73: 1-7$.

20）国土交通省中部地方整備局豊橋河川事務所. 矢作川空中 斜写真集. 2003; 1-34.

21）西条八束, 三田村緒佐武.「湖沼調査法」講談社, 東京. 1995; 197-206.

22）高橋勇夫. 四万十川河口域におけるアユの初期生活史に 関する研究. 高知大学海洋生物教育研究センター研究報 告 $2005 ; 23: 113-173$.
23）東 健作, 平賀洋之, 木下 泉. 降下仔アユの海域への 分散に及ぼす降水量の影響. 日水誌 2003; 69: 352-358.

24) Wada E, Kabaya $\mathrm{Y}$, Tsuru K, Ishiwatari R. ${ }^{13} \mathrm{C}$ and ${ }^{15} \mathrm{~N}$ abundance of sedimentary organic matter in estuarine areas of Tokyo Bay, Japan. Mass Spectroscopy 1990; 38: 307-318.

25) Mishima Y, Hoshika A, Tanimoto T. Deposition rates of terrestrial and marine organic carbon in the Osaka Bay, Seto Inland Sea, Japan, determined using carbon and nitrogen stable isotope ratios in the sediment. J. Oceanogr. 1999; 55: 1-11.

26) Mitsch WJ, Gosselink JG. Biogeochemistry of Wetlands. In: Mitsch WJ and Gosselink JG (eds) Wetlands. Van Nostrand Reinhold, New York. 1993; 114-163.

27）矢作川水産資源保護調査事業データ集(1998～2007 年). 豊田市矢作川研究所。 